\title{
A Study of Spatial Inequality in Blitar Area: Facilitating Worse-off People to Develop
}

Nurul Nur'aini'

\begin{abstract}
Spatial inequality is understood as the disparity among spatial units in a region perceived by the people. Some spatial units can provide proper and affordable public facilities and infrastructure while some others cannot. In Blitar region, spatial inequality is apparent between the North and South part of the region. In this case, the worse-off people (WOP) suffered the most from the situation. Brantas River stretching east-west in the region, marks the boundary dividing the territory into two parts: the North and South sub regions. So far, the North part appeared to be more developed than the South. This study was aimed to answer the question "how to facilitate the worse-off people to get more equitable benefits from the regional development". The study examined seven aspects of development, i.e. employment, income taxes, minimum wages, social security, educational services, health services and basic infrastructure. The study employed random sampling survey to the WOP of Blitar region, in proportion to the district units (kecamatan). Questionnaires provided perceptions from the WOP per household unit. The study found that the WOP living in the North do not always feel better than those in the South. The North WOP are better in terms of taxation, minimum wages and educational services, while the South WOP are better in the aspects of employment, health services and basic infrastructure. Policy implication analysis recommended immediate reformulations of two policies regarding employment and basic infrastructure, especially clean water and electricity.
\end{abstract}

Keyword: equity-based development, spatial inequality, worse-off people

\section{PENDAHULUAN}

Kesenjangan spasial merupakan perbedaan yang dirasakan oleh masyarakat pada unit-unit spasial pada suatu wilayah, dimana beberapa unit spasial dapat menikmati fasilitas umum dan infrastruktur yang layak dan terjangkau sementara beberapa yang lainnya tidak dapat menikmatinya (Kanbur dan Venables, 2003:2). Sebagian atau sekelompok masyarakat yang tidak dapat menikmati hasil-hasil dari pembangunan mereka termasuk ke dalam masyarakat kurang beruntung (worse-off people).

Dari data BPS (2003) jumlah penduduk miskin, Kabupaten Blitar menduduki peringkat tertinggi kedua yaitu sebesar 17,19\% setelah Kabupaten Malang. Pada tahun 2008, dalam penelitian Wirawan, kenyataan yang ada menunjukkan bahwa jumlah penduduk di bawah garis kemiskinan paling tinggi adalah di Jawa Timur untuk wilayah Pulau Jawa yaitu sebesar 7.578.100 jiwa, atau sekitar 20,93\% dari total penduduk Jawa Timur pada tahun tersebut. Selama kurun waktu 3 tahun yaitu 2005 sampai 2008, di wilayah Blitar ada kenaikan sebesar 4,6\% jumlah rumah tangga miskin yaitu dari 82.870 KK menjadi 86.642 KK (BPS, 2008). Untuk itu wilayah Blitar menjadi pilihan sebagai objek penelitian.

\footnotetext{
${ }^{1}$ Nurul Nur'aini adalah Staf Bidang Pembangunan Jalan dan Jembatan, Dinas PU Bina Marga dan Pengairan Kabupaten Blitar, Jawa Tengah

(c) 2012 Jurnal Pembangunan Wilayah dan Kota
} 
Blitar merupakan suatu wilayah yang terletak di bagian Selatan Jawa Timur, dengan luas $1621,37 \mathrm{~km}^{2}$. Secara administratif, wilayah Blitar berbatasan dengan tiga wilayah yakni di sebelah Timur dengan Kabupaten Malang, Barat dengan Kabupaten Tulungagung dan Kabupaten Kediri, Utara dengan wilayah Kabupaten Malang dan Kabupaten Kediri, sedangkan di sebelah Selatan berbatasan dengan Samudera Indonesia. Gambar peta wilayah Blitar dapat dilihat pada Gambar 1, dimana wilayah Blitar terbagi menjadi 25 kecamatan, dengan perincian 22 kecamatan masuk wilayah kabupaten dan tiga kecamatan masuk ke dalam wilayah Kota. Letak wilayah kota (warna putih) berada di tengah-tengah wilayah Kabupaten. Meskipun secara administratif kota dan kabupaten berbeda, namun keberadaan kota sebagai tempat pusat mempengaruhi wilayah sekitarnya. Keterkaitan dari berbagai segi seperti sosial, ekonomi, ataupun akses dalam perjalanan untuk bekerja, pencapaian fasilitas dan layanan yang membentuk suatu wilayah fungsional. Namun pada kenyataannya, pengaruh maupun hubungan yang terjadi tidaklah sama dimana menjadikan sebagian wilayah lebih berkembang dibandingkan bagian wilayah yang lain.

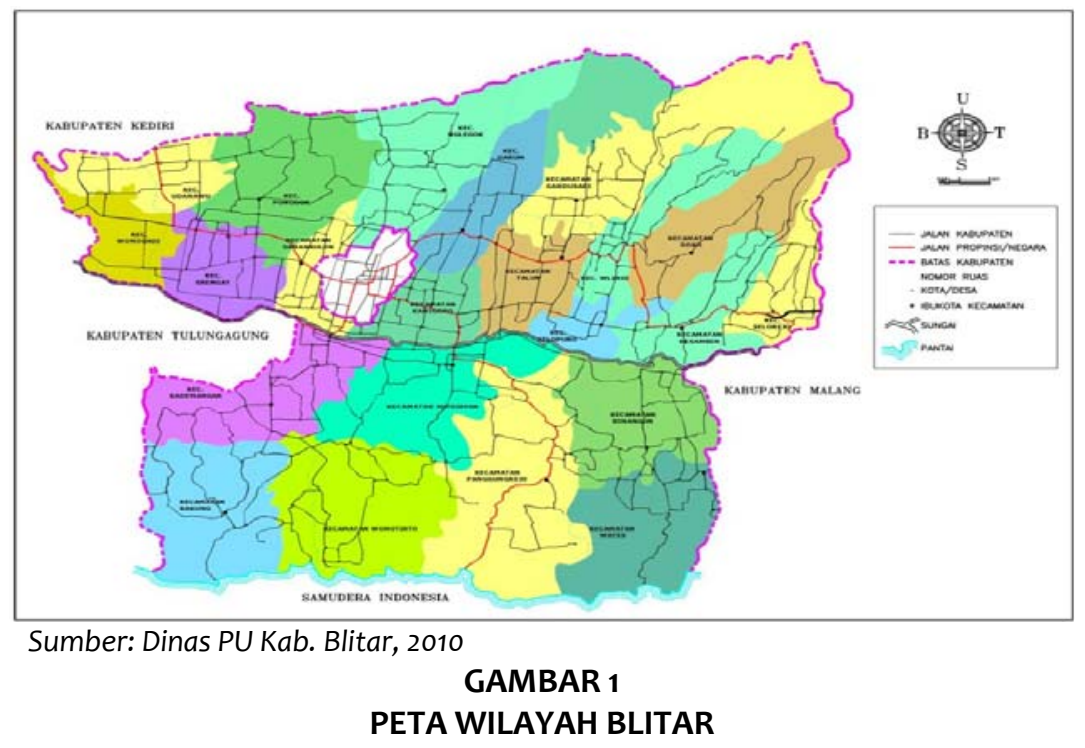

Dalam RTRW Kabupaten Blitar 2008 disebutkan adanya kesenjangan di Blitar, yaitu antara wilayah Utara dan Selatan. Pembagian Utara dan Selatan yang dimaksud adalah berdasarkan sungai Brantas yang mengalir dari Barat ke Timur sehingga membelah wilayah menjadi dua bagian. Kesenjangan tersebut ada dalam berbagai aspek seperti kepadatan penduduk, perekonomian, ketersediaaan fasilitas umum dan infrastruktur. Kondisi tersebut secara tidak langsung juga dipengaruhi oleh keberadaan pusat pemerintahan kabupaten yang saat ini masih di wilayah Kota Blitar. Hal ini berarti ada beberapa bagian wilayah Kabupaten Blitar yang mempunyai hubungan lebih besar dengan Kota Blitar dibanding dengan wilayah yang lain.

Isu kesenjangan bahkan telah diangkat dalam pemaparan visi dan misi pada pemilihan kandidat cawabup dari kader PDIP pemilu 2010 (PDI-P, 2010) dimana salah satu dari kandidat mempunyai visi untuk mengikis kesenjangan ekonomi antara Blitar Utara dan Selatan. Wilayah Utara memang lebih diuntungkan karena dilewati jalur yang merupakan penghubung dua wilayah yaitu Malang dan Kediri sehingga perkembangannya lebih cepat. Secara otomatis perekonomian lebih berjalan. Selain itu, pusat pemerintahan kabupaten berada di wilayah kota yang terletak di Utara lebih menunjang perkembangan wilayah. Lalu-lintas yang lebih padat serta fasilitas pelayanan publik seperti kantor pemerintahan, bank, dan jasa lainnya menjadikan perdagangan menjadi lebih maju. 
Distribusi manfaat pembangunan yang tidak merata bisa jadi menyebabkan kesenjangan, dan ini diduga merupakan sebuah indikasi dari tindakan ketidakadilan (Hamlin dan Lyons, 1996). Ada model pembangunan antar wilayah yang berbasis keadilan yang dikemukakan oleh Sugiri (2009) dimana dalam proses pembangunan agar kesejahteraan dapat tercapai harus menerapkan prinsip keadilan. Hasil-hasil pembangunan seharusnya dapat dinikmati secara adil oleh seluruh masyarakat tentunya sesuai dengan usaha yang mereka lakukan. Melihat kondisi yang ada dan di satu sisi terdapat masyarakat kurang beruntung yang tinggal di wilayah Blitar Utara dan Selatan maka diduga mereka merasakan kesenjangan spasial, sehingga hal ini menjadikan alasan untuk dikaji.

\section{METODE PENELITIAN}

Pendekatan pada penelitian ini menggunakan pendekatan kuantitatif yaitu dari awal, proses hingga akhir mempergunakan aspek pengukuran, perhitungan, rumus dan kepastian data numerik (Musianto, 2002:123). Kuesioner yang akan diberikan terdiri dari 7 bagian yang mana bagian tersebut adalah merupakan apek yang diduga mempengaruhi terjadinya kesenjangan. Sampel mewakili populasi masyarakat miskin yang berada di wilayah Blitar. Meskipun pada analisis mengkaji antara masyarakat miskin yang tinggal di Utara dan Selatan, namun dalam pengambilan sampel tidak ada pembedaan. Pengambilan sampel menggunakan sampling random (probability sampling) yaitu setiap unit dalam populasi mempunyai kesempatan yang sama untuk dipilih menjadi anggota sampel.

\section{GAMBARAN UMUM WILAYAH BLITAR}

Secara geografis, posisi wilayah Blitar Kota $112^{\circ} 14^{\prime}-112^{\circ} 28^{\prime}$ bujur Timur dan $8^{\circ} 2^{\prime}-8^{\circ} 8^{\prime}$ lintang Selatan, sedangkan kabupaten terletak diantara $111^{\circ} 40^{\prime}-112^{\circ} 10^{\prime}$ bujur Timur dan $7^{\circ} 58^{\prime}-8^{\circ} 9^{\prime} 51^{\prime \prime}$ lintang Selatan. Ketinggian rata-rata Kota Blitar adalah $\pm 156 \mathrm{~m}$ dari permukaan air laut, untuk bagian Utara ketinggian $245 \mathrm{~m}$ dari permukaan air laut dengan kemiringan $2^{\circ}-15^{\circ}$, bagian tengah $\pm 175 \mathrm{~m}$, dan bagian Selatan $\pm 140 \mathrm{~m}$ dengan kemiringan $0^{\circ}-2^{\circ}$, sehingga secara umum Kota Blitar termasuk dataran rendah. Sedangkan Kabupaten Blitar, ketinggian rata-ratanya adalah $\pm 167 \mathrm{~m}$, akan tetapi ada bagian yang mempunyai ketinggian di atas $300 \mathrm{~m}$ dari permukaan air laut, yaitu bagian Utara di 2 Kecamatan, Doko dan Gandusari, serta 3 kecamatan di bagian Selatan diantaranya Kecamatan Wates, Wonotirto, dan Panggungrejo.

Wilayah Blitar dilewati sungai Brantas yang membentang dari Barat ke Timur, sehingga membagi wilayah menjadi 2 bagian yaitu Utara dan Selatan, dimana kota termasuk bagian Utara. Wilayah Utara kondisinya lebih subur karena ada Gunung Kelud yang secara periodik meletus, sehingga dari abu vulkanik yang dikeluarkan membuat tanah menjadi subur. Selain itu, di bagian Utara banyak sungai yang mengalir dari runtutan Sungai Brantas. Sebaliknya, wilayah Selatan kondisi tanahnya kurang subur karena merupakan daerah perbukitan dan sulit untuk ditanami apalagi sangat terbatas sumber airnya.

\section{Rumah Tangga Miskin}

Tingkat kemiskinan yang dihitung dari perbandingan antara jumlah rumah tangga miskin dengan jumlah rumah tangga. Rata-rata tingkat kemiskinan secara keseluruhan wilayah Blitar adalah $21 \%$, nilai tersebut masih di atas tingkat kemiskinan secara nasional yaitu 14,15\% (BPS, 2009) dan 13,33\% (Bappenas, 2010). Dari hasil perhitungan yang ada maka dapat digambarkan seperti Gambar 2, dari degradasi warna menunjukkan perbedaan tingkat kemiskinan, semakin 
gelap maka tingkat kemiskinannya semakin tinggi. Dari gambar terlihat bahwa kondisi kemiskinan di wilayah Blitar hampir merata.

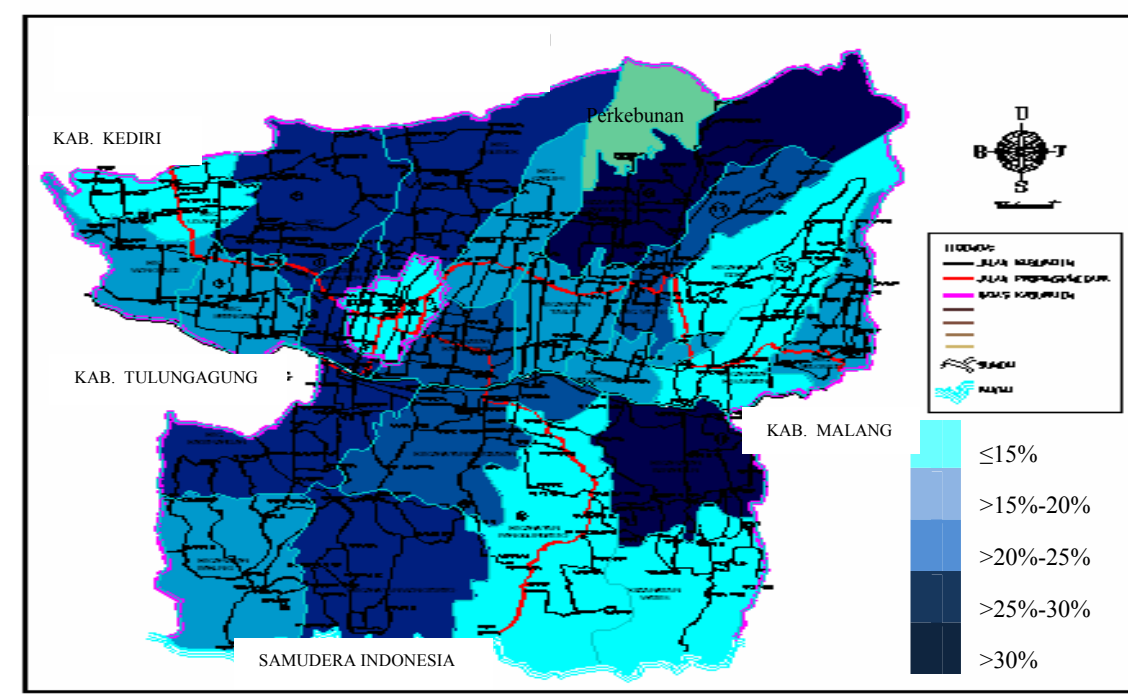

Sumber: Hasil Analisis, 2011

GAMBAR 2

TINGKAT KEMISKINAN DI WILAYAH BLITAR

\section{ANALISIS}

Dari hasil kuesioner yang diberikan kepada 100 orang responden masyarakat kurang beruntung berupa persepsi masyarakat dan berdasarkan fakta yang ada, maka hasil kesimpulannya dapat dilihat pada Tabel 1 berikut.

TABEL 1

HASIL KESIMPULAN PERBANDINGAN ANTARA PERSEPSI WOP DAN FAKTA

\begin{tabular}{|c|c|c|c|c|}
\hline No & Aspek & Persepsi & Fakta & Kesimpulan \\
\hline 1 & Ketenagakerjaan & $\begin{array}{l}\text { Kesempatan } \\
\text { lapangan kerja } \\
\text { dirasakan masih } \\
\text { sulit dan } \\
\text { kesulitan itu lebih } \\
\text { dirasakan oleh } \\
\text { WOP Utara } \\
\text { dibanding } \\
\text { dengan WOP } \\
\text { Selatan. }\end{array}$ & $\begin{array}{l}\text { Pabrik/industri skala besar } \\
\text { di wilayah Blitar kurang } \\
\text { dari } 1 \%, 99,64 \% \text { adalah } \\
\text { industri kecil rumah } \\
\text { tangga (Bappeda, 2008). } \\
\text { Mayoritas mata } \\
\text { pencaharian masyarakat } \\
\text { dari pertanian, } \\
\text { peternakan dan } \\
\text { perdagangan. } \\
\text { Terdapatnya sungai- } \\
\text { sungai yang lebih banyak } \\
\text { di wilayah Utara } \\
\text { memberikan peluang } \\
\text { penambangan pasir yang } \\
\text { lebih baik. }\end{array}$ & $\begin{array}{l}\text { Berdasarkan persepsi } \\
\text { masyarakat sulitnya } \\
\text { mendapatkan lapangan } \\
\text { pekerjaan karena tidak } \\
\text { adanya lapangan } \\
\text { pekerjaan atau } \\
\text { perusahaan yang mampu } \\
\text { menyerap tenaga kerja } \\
\text { yang lebih banyak seperti } \\
\text { perusahaan-perusahaan } \\
\text { besar atau } \\
\text { pabrik/industri. }\end{array}$ \\
\hline 2 & $\begin{array}{l}\text { Pajak } \\
\text { Pendapatan }\end{array}$ & $\begin{array}{l}\text { Beban pajak } \\
\text { dirasakan WOP }\end{array}$ & $\begin{array}{l}\text { Pajak diberlakukan sesuai } \\
\text { dengan peraturan dan }\end{array}$ & $\begin{array}{l}\text { Walaupun dalam } \\
\text { mendapatkan lapangan }\end{array}$ \\
\hline
\end{tabular}




\begin{tabular}{|c|c|c|c|c|}
\hline No & Aspek & Persepsi & Fakta & Kesimpulan \\
\hline & & $\begin{array}{l}\text { Utara cukup } \\
\text { sedangkan WOP } \\
\text { Selatan masih } \\
\text { agak terlalu } \\
\text { besar. }\end{array}$ & $\begin{array}{l}\text { perundang-undangan } \\
\text { yang ada. }\end{array}$ & $\begin{array}{l}\text { pekerjaan wilayah Utara } \\
\text { sedikit lebih sulit } \\
\text { dibandingkan dengan } \\
\text { Selatan tetapi dalam } \\
\text { membayarkan pajaknya } \\
\text { WOP Selatan merasa } \\
\text { masih agak terlalu berat } \\
\text { karena pendapatan dari } \\
\text { pekerjaan Utara masih } \\
\text { lebih baik. }\end{array}$ \\
\hline 3 & Upah Minimum & $\begin{array}{l}\text { WOP Selatan } \\
\text { merasa besaran } \\
\text { UMR lebih } \\
\text { memadai dari } \\
\text { WOP Utara. }\end{array}$ & $\begin{array}{l}\text { UMR yang diberlakukan } \\
\text { pemerintah sesuai } \\
\text { peraturan daerah. }\end{array}$ & $\begin{array}{l}\text { Karena biaya hidup yang } \\
\text { rendah maka besaran } \\
\text { UMR yang ditetapkan } \\
\text { pemerintah, maka WOP } \\
\text { Selatan merasa lebih } \\
\text { memadai untuk } \\
\text { kebutuhan sehari-hari } \\
\text { dibanding Utara. }\end{array}$ \\
\hline 4 & $\begin{array}{l}\text { Jaminan } \\
\text { Kesejahteraan } \\
\text { Sosial }\end{array}$ & $\begin{array}{l}\text { WOP Utara dan } \\
\text { Selatan } \\
\text { merasakan } \\
\text { kesamaan yaitu } \\
\text { keadaan saat ini } \\
\text { dengan } 5 \text { tahun } \\
\text { lalu adalah sama } \\
\text { saja. } \\
\end{array}$ & $\begin{array}{l}\text { Jamsostek, yaitu jaminan } \\
\text { kecelakaan kerja, jaminan } \\
\text { kematian, jaminan hari tua } \\
\text { dan jaminan pemeliharaan } \\
\text { kesehatan berdasarkan } \\
\text { UU No.3 tahun } 1992\end{array}$ & $\begin{array}{l}\text { Karena jenis Jaminan } \\
\text { Kesejahteraan Sosial yang } \\
\text { ada hanya bisa dirasakan } \\
\text { dan didapatkan pada } \\
\text { saat-saat tertentu saja, } \\
\text { maka baik Utara maupun } \\
\text { Selatan merasakan hal } \\
\text { yang sama. }\end{array}$ \\
\hline 5 & $\begin{array}{l}\text { Pelayanan } \\
\text { Pendidikan }\end{array}$ & $\begin{array}{l}\text { Dari segi } \\
\text { jangkauan } \\
\text { pendidikan WOP } \\
\text { Selatan merasa } \\
\text { lebih sulit dari } \\
\text { pada Utara. }\end{array}$ & $\begin{array}{l}\text { Fasilitas sekolah jenjang } \\
\text { SD dan SLTP sudah sangat } \\
\text { baik, jenjang SLTA } \\
\text { memenuhi standar 52\%, } \\
\text { masih kurang 32\% dan } \\
\text { tidak ada sama sekali } 16 \% . \\
\text { Dari aksesibilitas seluruh } \\
\text { wilayah Selatan masuk } \\
\text { kategori sulit, sedangkan } \\
\text { wilayah Utara Utara 44\% } \\
\text { sulit, 39\% cukup mudah, } \\
\text { dan } 17 \% \text { sangat mudah. } \\
\text { Jumlah angkutan umum di } \\
\text { wilayah Selatan terbatas } \\
\text { dan rute angkutan belum } \\
\text { merata (Bappeda, 2008) }\end{array}$ & $\begin{array}{l}\text { Kondisi alam yang } \\
\text { berbukit-bukit dan tidak } \\
\text { ditunjang dengan adanya } \\
\text { angkutan umum yang } \\
\text { melintas pada jam-jam } \\
\text { tertentu, menyebabkan } \\
\text { dalam menjangkau } \\
\text { fasilitas pendidikan yang } \\
\text { tersedia masih lebih sulit } \\
\text { dibanding Utara yang } \\
\text { kondisi alamnya berupa } \\
\text { daratan }\end{array}$ \\
\hline 6 & $\begin{array}{l}\text { Pelayanan } \\
\text { Kesehatan }\end{array}$ & $\begin{array}{l}\text { Dalam } \\
\text { pencapaian } \\
\text { pelayanan } \\
\text { kesehatan WOP } \\
\text { Utara justru } \\
\text { merasa lebih sulit } \\
\text { daripada Selatan. }\end{array}$ & $\begin{array}{l}\text { Tersedianya fasilitas } \\
\text { kesehatan Puskesmas } \\
\text { secara merata di setiap } \\
\text { kecamatan, } 9 \text { Rumah Sakit } \\
\text { dan } 2 \text { Rumah Sakit } \\
\text { Bersalin berada di wilayah } \\
\text { Utara. }\end{array}$ & $\begin{array}{l}\text { Karena segala penyakit } \\
\text { penanganannya lebih } \\
\text { dominan di Rumah Sakit } \\
\text { menyebabkan WOP Utara } \\
\text { merasa lebih sulit dalam } \\
\text { pembiayaan } \\
\text { dibandingkan dengan } \\
\text { Selatan yang } \\
\text { penanganannya cukup di } \\
\text { Puskesmas terdekat yang } \\
\text { biayanya lebih murah. }\end{array}$ \\
\hline
\end{tabular}




\begin{tabular}{|c|c|c|c|c|}
\hline No & Aspek & Persepsi & Fakta & Kesimpulan \\
\hline 7 & $\begin{array}{l}\text { Infrastruktur } \\
\text { berupa jalan, listrik, } \\
\text { air bersih, saluran } \\
\text { drainase serta } \\
\text { telekomunikasi }\end{array}$ & $\begin{array}{l}\text { Atas pembangunan } \\
\text { infrastruktur yang } \\
\text { telah dilaksanakan } \\
\text { oleh pemerintah } \\
\text { tingkat kepuasan } \\
\text { yang dirasakan } \\
\text { WOP Selatan (92\%) } \\
\text { lebih tinggi dari } \\
\text { WOP Utara (71\%). } \\
\text { Dalam hal } \\
\text { kebutuhan } \\
\text { infrastruktur yang } \\
\text { perlu ditingkatkan, } \\
\text { WOP Utara listrik } \\
\text { (73\%) dan WOP } \\
\text { Selatan air bersih } \\
\text { (88\%). }\end{array}$ & $\begin{array}{l}\text { Informasi dari Dinas PU } \\
\text { bahwa Pemerintah Blitar } \\
\text { dalam melaksanakan } \\
\text { pembangunan bidang } \\
\text { infrastruktur selain dari PAD } \\
\text { juga mendapat bantuan dari } \\
\text { pemerintah propinsi maupun } \\
\text { pusat, sehingga dengan } \\
\text { anggaran yang cukup besar } \\
\text { tersebut pembangunan } \\
\text { infrastruktur jalan di wilayah } \\
\text { Blitar terbilang pesat dalam } 5 \\
\text { tahun belakangan ini. } \\
\text { Listrik telah menjangkau ke } \\
\text { seluruh kawasan } \\
\text { permukiman di wilayah Blitar. } \\
\text { Untuk pemenuhan air } \\
\text { wilayah Blitar Selatan masih } \\
\text { cukup kesulitan dan hanya } \\
\text { mengandalkan air sumur dan } \\
\text { mata air, selain itu masih } \\
\text { kurangnya pengelolaan } \\
\text { sumber-sumber air } \\
\text { (Bappeda, 2008). }\end{array}$ & $\begin{array}{l}\text { WOP Selatan sangat } \\
\text { membutuhkan pelayanan air } \\
\text { bersih karena wilayah } \\
\text { Selatan merupakan wilayah } \\
\text { yang gersang sehingga } \\
\text { untuk mendapatkan sumber } \\
\text { air sangat sulit. Untuk } \\
\text { masalah listrik agaknya WOP } \\
\text { Utara lebih membutuhkan } \\
\text { daya yang lebih besar dari } \\
\text { daya yang sudah ada saat } \\
\text { ini. }\end{array}$ \\
\hline
\end{tabular}

Sumber: Hasil Analisis, 2011

Selanjutnya dari ketujuh aspek dinilai besarnya ketidakadilan yang dirasakan oleh WOP Utara dan Selatan. Hasil penilaiannya dapat dilihat pada Tabel 2 berikut ini.

TABEL 2

PENILAIAN KETIDAKADILAN YANG DIRASAKAN WOP UTARA DAN SELATAN WILAYAH BLITAR

\begin{tabular}{llllll}
\hline No. & Aspek & Skor & Nilai & $\begin{array}{l}\text { Kategori } \\
\text { Keadilan }\end{array}$ & Prioritas \\
\hline 1. & Ketenagakerjaan (kesempatan) & 2,07 skala 5 & 2,07 & Parah & 1 \\
\hline 2. & Pajak (beban) & 1,74 skala 3 & 2,90 & Moderat & 5 \\
\hline 3. & Upah/Gaji Minimal (ketetapan) & 2,27 skala 4 & 2,84 & Moderat & 6 \\
\hline 4. & $\begin{array}{l}\text { Jaminan Kesejahteraan Sosial } \\
\text { (jaminan) }\end{array}$ & 2,29 skala 4 & 2,86 & Moderat & 7 \\
\hline 5. & $\begin{array}{l}\text { Pelayanan Pendidikan } \\
\text { (kecukupan) }\end{array}$ & 1,61 skala 2 & 4,03 & Ringan & \multicolumn{2}{l}{4} \\
\hline 6. & $\begin{array}{l}\text { Pelayanan Kesehatan } \\
\text { (kecukupan) }\end{array}$ & 1,53 skala 2 & 3,83 & Ringan & 3 \\
\hline 7. & Infrastruktur (kecukupan) & 1,35 skala 2 & 3,38 & \multicolumn{2}{l}{ Moderat } \\
\hline
\end{tabular}

Sumber: Hasil Analisis, 2011

\section{Keterangan:}

Kategori Nilai Keadilan:

$$
\begin{aligned}
& 5=\text { Adil } \\
& 4=\text { Ringan } \\
& 3=\text { Moderat } \\
& 2=\text { Parah } \\
& 1=\text { Sangat Parah }
\end{aligned}
$$




\section{KESIMPULAN}

Berdasarkan analisis dapat disimpulkan memang benar ada kesenjangan spasial di wilayah Blitar dari beberapa aspek antara WOP yang tinggal di bagian Utara dan Selatan Sungai Brantas, meskipun besarnya tidak signifikan.

Ketidakadilan yang dirasakan WOP Utara lebih pada aspek:

1. Ketenagakerjaan

2. Pelayanan kesehatan

3. Infrastruktur

Sedangkan WOP Selatan pada aspek:

1. Pajak

2. Upah/gaji minimal

3. Pelayanan pendidikan

Dari aspek penilaian kebijakan oleh WOP yang menjadi prioritas pertama perlunya direformulasikan adalah kebijakan ketenagakerjaan dan yang kedua adalah infrastruktur.

\section{DAFTAR PUSTAKA}

Abidin, S.Z. 2004. Kebijakan Publik. Edisi Revisi. Jakarta: Yayasan Pancur Siwah.

Adisasmita, R. 2005. Dasar-Dasar Ekonomi Wilayah. Yogyakarta: Graha Ilmu.

Arikunto, S. 2006. Prosedur Penelitian: Suatu Pendekatan Praktek. Jakarta: Rineka Cipta.

Astuti dan Musiyam. 2009. "Kemiskinan dan Perkembangan Wilayah di Kabupaten Boyolali." Forum Geografi, Vol. 23, No. 1, Juli 2009: 71-85.

Giyanto, B. 2008. "Strategi Penanggulangan Kemiskinan (Studi Kasus DKI Jakarta)." Jurnal Borneo Administrator. Volume 4 No. 2.

Hamlin, R.E. and Lyons, T.S. 1996. Economy Without Walls. Connecticut: Praeger.

Hill, Hal. 1998. "The Challenge of Regional Development in Indonesia." Australian Journal of International Affairs. Vol. 52 no.1.

Jhingan, M.L. 1996. Ekonomi Pembangunan \& Perencanaan. Edisi 16. Jakarta: Raja Grafindo Persada.

Kanbur, R. and A.J. Venables 2005. "Spatial Inequality and Development." Journal of Economic Geography, Special Issue, 5 (1).

Lo, Fu Chen \& Salih, Kamal. 1978. Growth Pole Strategy \& Regional Development Policy Asian Experience and Alternative Approaches. UNCRD. Nagoya, Japan: Pergamon Press.

Li, Y. and Y.H.D. Wei 2010. The Spatial-Temporal Hierarchy of Regional Inequality of China, Applied Geography, 30, 303-316.

Pieterse, J.N. 2001. Development Theory: Deconstructions/Reconstructions, London: SAGE Publications.

Rustiadi, E. 2001. Paradigma Baru Dalam Pembangunan Wilayah Di Era Otonomi Daerah. Lokakarya Otonomi Daerah. Jakarta: Perak Study Club Center.

Rondinelli, Dennis A and Kenneth Ruddle. 1978. Urbanization and Rural Development: A Spatial Policy for Equitable Growth. New York: Praeger Publisher.

Soetrisno, Loekman. 1997. Kemiskinan, Perempuan dan Pemberdayaan. Yogyakarta: Kanisius. Tarigan, Robinson. 2004. Perencanaan Pembangunan Wilayah. Jakarta: Bumi Aksara.

Williamson, J.G. 1975. Regional Inequality and The Process of National Development - A Description of The Patterns. Friedman and Alonso (ed). Regional Policy. Reading in Theory and Application. Cambridge: MIT Press. 